\title{
Metacognitive Knowledge and Its Effect on Second Language Writing: Students' Perceptions of Writing Task
}

\author{
Narges Saffari ${ }^{1}$ \\ ${ }^{1}$ English Department, Faculty of Languages and Linguistics, University of Malaya, Kuala Lumpur, Malaysia \\ Correspondence: Narges Saffari, English Department, Faculty of Languages and Linguistics, University of Malaya, \\ Kuala Lumpur, Malaysia. E-mail: narges.saffari1@gmail.com
}

Received: August 8, 2019

Accepted: September 2, 2019

Online Published: September 3, 2019

doi:10.5430/ijhe.v8n5p221

URL: https://doi.org/10.5430/ijhe.v8n5p221

\begin{abstract}
Metacognitive knowledge is a comparatively constant information show how human beings learn and process information in general and individual. It is also considered as a significant element in learners' achievement inside and outside the classroom. The purpose of this paper is to understand the knowledge and beliefs L2 learners bring to writing tasks, and how the metacognitive knowledge they possess influences their approach to L2 writing. Fifty undergraduate students were asked to fill the questionnaire and express their opinion on this matter. Findings of response data from questionnaires indicate that EFL writing is positively related to attention on the macro-level structure and negatively related to micro-level concerns.
\end{abstract}

Keywords: metacognitive knowledge, rhetorical structures, second language writing, second language students

\section{Introduction}

L2 learners' knowledge and beliefs about writing may be culturally shaped. Researchers (Devine, Railey, \& Boshoff, 1993; Kasper, 1997; Victori, 1999) have suggested that L2 learners' defined knowledge and beliefs about writing may affect the success of their approach to L2 writing tasks and the success of the outcome. That is, L2 writers may lack appropriate metacognitive knowledge about the requirements and processes involved in undertaking an L2 writing task (Biggs, Lai, Tang, \& Lavelle, 1999). A coherent theory of L2 writing needs to include concern for more fully understanding students' knowledge and beliefs that may influence the learner's approach towards a writing task. Yet, there is slight research on L2 writers' knowledge and beliefs comparing their L1 writing backgrounds to their experiences as L2 language learners and their L2 writing performance.

The improvement of metacognitive theory provides a viewpoint on the self-regulatory improvements of observing and task analysis L2 learners which may involve in when they are writing. L2 writer should be aware of their cognitive processes (metacognitive knowledge) to work and create existing writing skills. Influenced by previous experiences in L1 writing, or shaped by their cultural backgrounds, L2 learners may apply their learned knowledge from previous L1 writing experience to L2 writing tasks. An analysis of L2 writers' metacognitive knowledge will be shown in this paper to spread the framework of writing through cultures and languages.

\section{Literature Review}

Metacognitive knowledge is developed as a result of personal experience, and the instruction one has received. In L2 literature, metacognitive knowledge is also referred to as learner beliefs (Horwitz, 1987). Flavell (1987) suggests that beliefs about learning are a basic element of metacognitive knowledge. There is no clear agreement on the difference between knowledge and beliefs, or certainly whether it is possible to make a difference between them. (Wenden, 1999).

Flavell (1985) divided the metacognitive knowledge base into three interactive variables: personal variables, task variables, and strategy variables. With this metacognitive perspective, different research approaches to writing can be described as focusing on different knowledge. Process-oriented studies are generally carried out within the framework of emphasising knowledge of strategies, planning, monitoring, and revision (Bereiter \& Scardamalia, 1987; Hayes \& Flower, 1980; Raimes, 1985; Zamel, 1983), while text-oriented research emphasises task variables, such as rhetorical difficulties and audience consideration. Metacognitive knowledge has been shown to influence two key phases in self-regulation: monitoring and task analysis (Wenden, 1999). In a study of Englert, Raphael and Anderson (1992), students showed greater ability to talk about planning, drafting and revising, as well as to discuss 
their purposes and planned audience, after participating in the writing interference that emphasized the process of writing, writing strategies, the role of teacher-student and student-student dialogue. The quality of these students' metacognitive knowledge was positively related to measures of academic performance in writing. In terms of task analysis, McCutchen, Francis, and Kerr (1997) observed how middle-school students revised texts where both spelling and meaning errors had been established. Skilled writers quickly developed the concept of the macrostructure of the text. In contrast, less-skilled writers rarely considered the global structure of the text. Instead, they examined sentences individually. Such a strategy made it difficult for them to perceive errors involved at a discourse level. In metacognitive terms, a good learner is "one who has plenty metacognitive knowledge about the self as a learner, about the nature of the cognitive task at hand, and about appropriate strategies for achieving cognitive goals" (Devine, 1993, p. 109). Devine, Railey, and Boshoff (1993) investigated cognitive models of less-skilled L1 and L2 writers and found that there was a significant positive correlation between metacognitive knowledge and writing performance. This finding was also reported by Kasper (1997), who assessed the metacognitive growth of ESL writers. Victori (1999) proposed that what differentiates good and poor EFL writers is a metacognitive knowledge base that determines the type of strategy or writing approach to be adopted by the writer. These studies provide evidence for the importance of metacognitive knowledge in second language writing. Furthermore, Cava (1999) found that unsuccessful L2 writers' poor personal knowledge, such as their self-concept, self-assessment, anxiety, and self-confidence, negatively influenced their performance and use of metacognitive strategies, although these L2 writers are also working many strategies believed necessary for good writing. This finding suggests that having appropriate personal knowledge seems to be serious to successful writing.

\section{Method}

A self-assessment questionnaire was used to describe the possibility of a relationship between the writers' metacognitive knowledge and their writing performance and explain the nature of L2 writing in terms of factors that likely influence writing ability. To examine the correlation, students' writing score was divided into three groups, namely, group 1 as low, group 2 as a medium, and group 3 as high. The questionnaire focused on the knowledge of writing conventions, prior experiences, and perceptions about writing. Following analyses examined (1) whether perceptions of English writing and Persian writing are different, and (2) whether there is a relationship between metacognitive knowledge in writing and writing outcomes. Questions about perceptions of English and Persian writing were enclosed for the sake of comparison. A five-point Likert scale was used to collect the participants' perception. Depending on how the respondent completes the 5-point scale for each statement, it may not be possible to determine discrimination among the four items of a set. For example, students can tick "agree" for all of the four items. Hence, the ranking order (item-e) was used to determine the priorities between the questionnaire items. Responses to questions which are structured in a 5-point scale were analysed by using frequency distributions. To determine the rank, the Kendall coefficient of concordance (Kendall's W) was used to provide a combining order according to a significant agreement (1999).

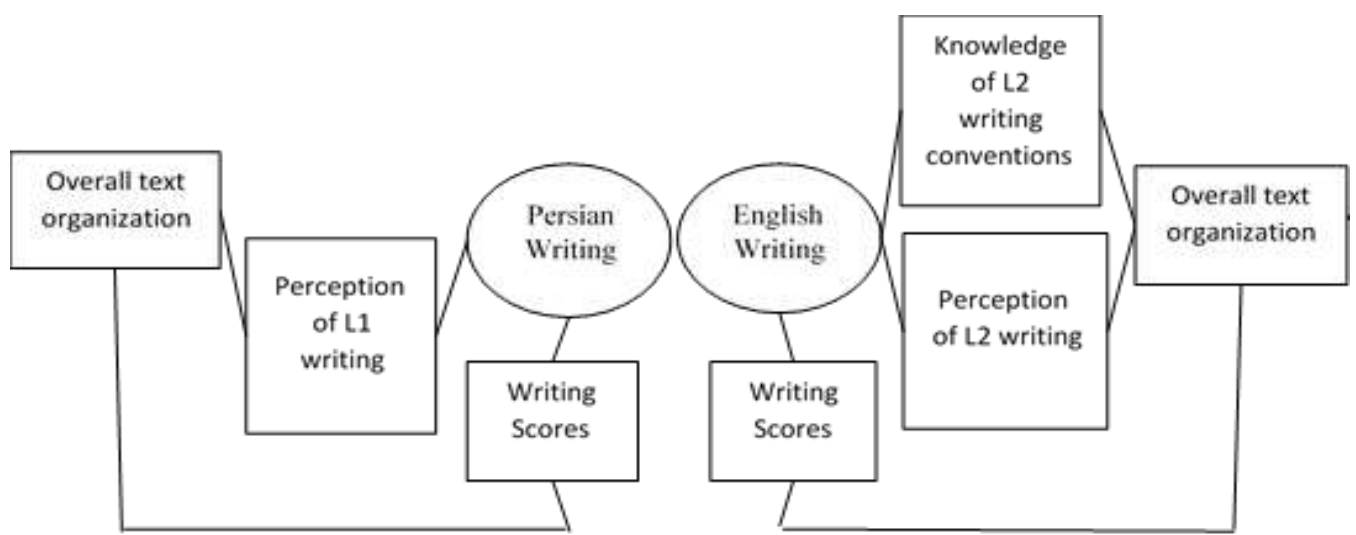

Figure 5. An overview of analytical procedures for metacognitive knowledge

\section{Results}

\subsection{Knowledge of English Writing Conventions and Writing Techniques}

Knowledge of writing conventions was examined through the frequency distribution of "never, rarely, sometimes, often, and always" responses. Response data about knowledge of English writing conventions were shown in Table 1. 
It indicated that participants perceived what they had learned. Moreover, the perception of respondents regarding the techniques they use to write in the English language was also examined through the frequency distribution of "strongly disagree, disagree, neither agree nor disagree, agree and strongly agree". The main purpose of these questions was to know how the students compose their writing.

Table 3. Frequency and percentage of respondents' knowledge of English writing conventions

\begin{tabular}{|c|c|c|c|c|}
\hline English writing in primary school (1) & Frequency & Percentage & Mean & Std. Deviation \\
\hline never & 30 & 60.0 & \multirow{5}{*}{1.60} & \multirow{5}{*}{.88} \\
\hline rarely & 12 & 24.0 & & \\
\hline sometimes & 7 & 14.0 & & \\
\hline always & 1 & 2.0 & & \\
\hline Total & 50 & 100.0 & & \\
\hline \multicolumn{5}{|c|}{ English writing in secondary school (2) } \\
\hline never & 12 & 24.0 & \multirow{6}{*}{2.36} & \multirow{6}{*}{1.08} \\
\hline rarely & 17 & 34.0 & & \\
\hline sometimes & 14 & 28.0 & & \\
\hline often & 5 & 10.0 & & \\
\hline always & 2 & 4.0 & & \\
\hline Total & 50 & 100.0 & & \\
\hline \multicolumn{5}{|c|}{ English writing in university (3) } \\
\hline never & 3 & 6.0 & \multirow{6}{*}{3.14} & \multirow{6}{*}{1.08} \\
\hline rarely & 12 & 24.0 & & \\
\hline sometimes & 15 & 30.0 & & \\
\hline often & 15 & 30.0 & & \\
\hline always & 5 & 10.0 & & \\
\hline Total & 50 & 100.0 & & \\
\hline \multicolumn{5}{|c|}{ Using own idea for writing (4) } \\
\hline never & 1 & 2.0 & \multirow{6}{*}{3.34} & \multirow{6}{*}{.91} \\
\hline rarely & 6 & 12.0 & & \\
\hline sometimes & 24 & 48.0 & & \\
\hline often & 13 & 26.0 & & \\
\hline always & 6 & 12.0 & & \\
\hline Total & 50 & 100.0 & & \\
\hline \multicolumn{5}{|c|}{ Using vocab and idioms for writing (5) } \\
\hline never & 2 & 4.0 & \multirow{6}{*}{3.20} & \multirow{6}{*}{.94} \\
\hline rarely & 9 & 18.0 & & \\
\hline sometimes & 19 & 38.0 & & \\
\hline often & 17 & 34.0 & & \\
\hline always & 3 & 6.0 & & \\
\hline Total & 50 & 100.0 & & \\
\hline \multicolumn{5}{|c|}{ Using correct grammar (6) } \\
\hline never & 1 & 2.0 & \multirow{5}{*}{3.72} & \multirow{5}{*}{.88} \\
\hline sometimes & 22 & 44.0 & & \\
\hline often & 16 & 32.0 & & \\
\hline always & 11 & 22.0 & & \\
\hline Total & 50 & 100.0 & & \\
\hline \multicolumn{5}{|c|}{ How to organise writing (7) } \\
\hline rarely & 12 & 24.0 & \multirow{4}{*}{3.08} & \multirow{4}{*}{.75} \\
\hline sometimes & 22 & 44.0 & & \\
\hline often & 16 & 32.0 & & \\
\hline Total & 50 & 100.0 & & \\
\hline
\end{tabular}

Based on Table 1, $60 \%$ of the students $(\mu=1.60)$ did not have English writing exposure when they were at primary school as well as secondary school $(34 \%)(\mu=2.36) .48 \%$ of students said they had learned how to use their idea for English writing occasionally ( $\mu=3.34$ ), followed by $19 \%$ and $44 \%$ of the selected option "sometimes" in regards with 
the use proper vocabulary and idioms $(\mu=3.2)$, the use of correct grammar $(\mu=3.7)$, and to organize their writing properly $(\mu=3.08)$, respectively.

The sum of four English writing conventions (Items: 4, 5, 6,7) was taken as the level of knowledge of English rhetoric structures (Chao, 2003). The purpose is to examine the relationship between students knowing English rhetoric structures and their English writing performance. The result of Pearson correlation indicates a statistically significant, positive and moderate relationship, $\mathrm{r}=0.484$, $(\mathrm{P}<0.01)$

Table 4. the result of Pearson correlation

\begin{tabular}{|c|c|c|c|}
\hline & & $\begin{array}{c}\text { level of knowledge of } \\
\text { English rhetoric structures }\end{array}$ & Writing Score \\
\hline \multirow{3}{*}{$\begin{array}{l}\text { level of knowledge of English } \\
\text { rhetoric structures }\end{array}$} & Pearson Correlation & 1 & $.484^{* *}$ \\
\hline & Sig. (2-tailed) & & .000 \\
\hline & $\mathrm{N}$ & 50 & 50 \\
\hline \multirow[t]{3}{*}{ Writing score } & Pearson Correlation & $.484^{* *}$ & 1 \\
\hline & Sig. (2-tailed) & .000 & \\
\hline & $\mathrm{N}$ & 50 & 50 \\
\hline
\end{tabular}

**. Correlation is significant at the 0.01 level (2-tailed).

\subsection{Students' Perception of English and Persian Writing Techniques}

Questions about perceptions of writing were compared between English and Persian to investigate how perceptions of writing may differ across the two languages. The questionnaire items were inspired by ideas from Zia Houseini and Derakhshan (2006), Mu and Carrington (2007), Wolfe, Britt, and Butler (2009), and Saneh (2009). According to the respondents' writing scores, the questionnaire was divided into three groups to analyse their perceptions pertaining to the items.

Table 5. essential characteristics of good English composition

\begin{tabular}{cccc}
\hline I think reading and more writing practice are essential for having a good English Composition (4/A) \\
\hline G1 & Valid & Mean & SD \\
G2 & 21 & 2.57 & .925 \\
G3 & 20 & 3.70 & .978 \\
Total & 09 & 3.77 & .971 \\
\hline I think learning vocabulary, idioms, and phrases are essential for having a good English Composition (4/B) \\
\hline G1 & 21 & 4.14 & .654 \\
G2 & 20 & 2.75 & 1.409 \\
G3 & 09 & 4.33 & .707 \\
Total & 50 & & \\
\hline I think using proper grammar and structure are essential for having a good English Composition (4/C) \\
G1 21 & 4.28 & .643 \\
G2 & 20 & 2.00 & .725 \\
G3 & 09 & 2.88 & 1.452 \\
Total & 50 & & \\
\hline I think learning about how to organise a text is essential for having a good English Composition (4/D) \\
G1 & 21 & 2.66 & 1.316 \\
G2 & 20 & 3.85 & .833 \\
G3 & 09 & 4.22 & \\
Total & 50 & & \\
\hline
\end{tabular}


Table 3 indicated that student from group 1 who belongs to low proficiency in English writing score, disagreed that lack of idea is essential to have a good English composition. On the other hand, group 2 and group 3 who obtained the average and high score in their English writing agreed that idea is one of the essential factors for having good writing. The low group, as well as high group, agreed vocabulary is important element regarding English writing besides other elements. However, the mid group believed that it is not as important as other factors. Only group 1 agreed that grammar and structure are very important in English writing by the mean score of $\mu=4.28$ and none of the students from group 2 and group 3 did not agree that having proper structure is needed in English writing with the mean of $\mu=2.00$ and $\mu=2.88$. Finally, the results indicate that students from a high level of English writing proficiency believed that learning about how to organise a text according to the language principle is the most important factor that every student should know to acquire better achievement in English writing. However, from group 1 and slightly group 2, this item was not important than other ones.

Table 6. The most difficult area in English composition

\begin{tabular}{|c|c|c|c|}
\hline \multicolumn{4}{|c|}{ I think the lack of ideas is the main difficulty in English composition (5/A) } \\
\hline & Valid & Mean & Std. Deviation \\
\hline G1 & 21 & 2.66 & 1.390 \\
\hline G2 & 20 & 3.85 & .745 \\
\hline G3 & 09 & 4.11 & .781 \\
\hline Total & 50 & & \\
\hline \multicolumn{4}{|c|}{ I think lack of lexical items, idioms, and phrases are the main difficulty in English Composition (5/B) } \\
\hline G1 & 21 & 3.85 & .963 \\
\hline $\mathrm{G} 2$ & 20 & 2.65 & 1.039 \\
\hline G3 & 09 & 3.11 & 1.364 \\
\hline Total & 50 & & \\
\hline \multicolumn{4}{|c|}{ I think the lack of grammar and structure are the main difficulty in English Composition (5/C) } \\
\hline G1 & 21 & 4.00 & 1.224 \\
\hline $\mathrm{G} 2$ & 20 & 2.55 & 1.234 \\
\hline G3 & 09 & 3.55 & .881 \\
\hline Total & 50 & & \\
\hline \multicolumn{4}{|c|}{ I think lack of knowledge regarding how to organise a text is the main difficulty in English Composition (5/D } \\
\hline G1 & 21 & 2.85 & 1.062 \\
\hline $\mathrm{G} 2$ & 20 & 3.90 & 1.020 \\
\hline G3 & 09 & 3.77 & .971 \\
\hline Total & 50 & & \\
\hline \multicolumn{4}{|c|}{ I think punctuation is the main difficulty in English composition (5/D) } \\
\hline $\mathrm{G} 1$ & 21 & 2.28 & 1.488 \\
\hline $\mathrm{G} 2$ & 20 & 3.15 & 1.039 \\
\hline G3 & 09 & 2.00 & 1.000 \\
\hline Total & 50 & & \\
\hline \multicolumn{4}{|c|}{ I think spelling (formal v. informal) is the main difficulty in English Composition (5/D) } \\
\hline G1 & 21 & 3.04 & .920 \\
\hline $\mathrm{G} 2$ & 20 & 3.35 & 1.089 \\
\hline G3 & 09 & 3.44 & 1.236 \\
\hline Total & 50 & & \\
\hline
\end{tabular}


As it can be observed from the above, lack of proper grammar is the most problematic area for students who belong to group 1 as low in English writing scores and followed by vocabulary and spelling as well. While, they perceived a lack of idea, text organisation and punctuation to be the least problematic area in English writing. The students with low English writing scores seemed to focus on surface-level errors, which show their concern in language accuracy difficulties. This is also what many scholars (Schulz, 2001; Diab, 2005; Diab, 2006; Rahimi, 2010) have found in their studies. Diab (2006, p. 3) asserts "surface-level correction is often what students want and expect from their teachers". This showed that students need more time to be spent on learning and checking grammar before handing in a piece of writing in class. On the contrary, the students from middle and high performing groups thought that along with vocabulary, grammar, and spelling which are important and problematic in English writing, lack of idea and text organisation is equally important for high-quality English writing. These students paid attention to both side of writing that is micro and macrostructures.

Using the ranking orders ("_>, _, _, _ ”) of the four items in a set to acquire best results for examining whether students placed different emphases in terms of top-structures and bottom-structures. Kendall's W and chi-squared tests were used to provide the item's order. Kendall's W is a nonparametric test of the hypothesis that several related samples are from the same population, which measures the agreement of raters. Each case is a judge, and each variable is an item being judged. For each variable, the sum of the ranks is computed. Kendall's W ranges between 0 (no agreement) and 1 (complete agreement). When the value of chi-square is significant, there is a significant agreement in how the judges view the importance of the item. Response data of the rankings in the two contrastive sets of questions are shown in sections below.

Table 7. Perceptions of L1\&L2 Writing

\begin{tabular}{|c|c|c|c|c|c|c|}
\hline \multicolumn{7}{|c|}{ Perceived approaches to good writing } \\
\hline \multirow[t]{2}{*}{ Items } & \multicolumn{3}{|c|}{ Mean rank (English) } & \multicolumn{3}{|c|}{ Mean rank (Persian) } \\
\hline & G1 & $\mathrm{G} 2$ & G3 & G1 & $\mathrm{G} 2$ & G3 \\
\hline $4 / \mathrm{A}$ & 3.29 & 2.10 & 2.11 & 1.27 & 2.32 & 2.36 \\
\hline 4/B & 1.71 & 3.00 & 2.56 & 2.55 & 3.32 & 2.45 \\
\hline $4 / \mathrm{C}$ & 1.86 & 3.00 & 3.33 & 2.64 & 2.86 & 3.45 \\
\hline 4/D & 3.14 & 1.90 & 2.00 & 3.55 & 1.50 & 1.73 \\
\hline Valid & 21 & 20 & 09 & 11 & 28 & 11 \\
\hline Chi-Square & $25.971 * *$ & $12.240 * *$ & 5.933 & $17.291 * *$ & $30.814 * *$ & $10.091 * *$ \\
\hline Kendall's Wa & .412 & .204 & .220 & .524 & .367 & .306 \\
\hline df & 3 & 3 & 3 & 3 & 3 & 3 \\
\hline Asymp. Sig. & .000 & .007 & .115 & .001 & .000 & .018 \\
\hline \multicolumn{7}{|c|}{ perceived difficulties in writing } \\
\hline Items & \multicolumn{3}{|c|}{ Mean rank (English) } & \multicolumn{3}{|c|}{ Mean rank (Persian) } \\
\hline & G1 & $\mathrm{G} 2$ & G3 & G1 & $\mathrm{G} 2$ & G3 \\
\hline $5 / \mathrm{A}$ & 4.00 & 2.75 & 2.56 & 2.45 & 2.14 & 2.45 \\
\hline $5 / \mathrm{B}$ & 1.76 & 4.00 & 2.89 & 2.45 & 2.54 & 2.55 \\
\hline $5 / \mathrm{C}$ & 2.19 & 3.90 & 3.33 & 3.36 & 5.11 & 3.00 \\
\hline $5 / \mathrm{D}$ & 4.00 & 2.45 & 2.00 & 3.73 & 2.75 & 3.36 \\
\hline $5 / \mathrm{E}$ & 4.29 & 4.60 & 5.78 & 5.18 & 5.04 & 5.82 \\
\hline $5 / \mathrm{F}$ & 4.76 & 3.30 & 4.44 & 382 & 3.43 & 3.82 \\
\hline Valid & 21 & 20 & 09 & 11 & 28 & 11 \\
\hline Chi-Square & $44.67 * *$ & $19.00 * *$ & $24.74 * *$ & $16.29 * *$ & $66.24 * *$ & $24.35^{* *}$ \\
\hline Kendall's Wa & .425 & .190 & .550 & .296 & .473 & .443 \\
\hline df & 5 & 5 & 5 & 5 & 5 & 5 \\
\hline Asymp. Sig. & .000 & .002 & .000 & .006 & .000 & .000 \\
\hline
\end{tabular}

*.Kendall's Coefficient of Concordance. $* * \mathrm{p}<.01, * \mathrm{p}<.05$

*.Note: If the priority order is $\mathrm{a}>\mathrm{b}>\mathrm{c}>\mathrm{d}$, then $\mathrm{a}, \mathrm{b}, \mathrm{c}, \mathrm{d}$ are coded as $1,2,3,4$ respectively. Thus, the lower the mean, the higher the rank. Numbers in parentheses indicate the group ranks. One the first rank and four the least.

*.Numbers in parentheses indicate the group ranks. 
As shown in the table 5, in terms of the main difficulty, perceptions differed. Group 1 held the different belief that to have an extensive vocabulary and idioms was the best approach to writing $(\mu=1.71)$ and grammar and proper structure were essential for good writing. Although many students from group 2 and group 3 believed that text organization would improve their writing the most $(\mu=1.90$ and $\mu=2.00$ for English writing) and $(\mu=1.50$ and $\mu=1.73$ for Persian writing), they believed that to read and practice more (item 4/A) was the best approach to writing ( $\mu=2.10$ and $\mu=2.11$ for English writing) and ( $\mu=2.32$ and $\mu=2.36$ for Persian writing), respectively. The results of personal knowledge (5/A to 5/F) indicated that all the groups had the same belief that lack of idea is more problematic for writing in Persian (group $1 \mu=2.45$, group $2 \mu=2.14$, group $3 \mu=2.55$ ). The results showed that all of the groups reported have an idea (item 5/A) as of the most important factors. They believed what differentiates a good essay from a poor essay was the idea (item5/A), so that they spent the most time generating the ideas.

In contrast, students from group 1 believed that the greatest difficulty in writing English (item 5/B) was the lack of lexical items $(\mu=1.76)$ and lack of proper grammar and structure $(\mu=2.30)$. This finding indicated that these Iranian undergraduate students who had low scores in their English writing had limited confidence in their ability to access words to communicate ideas they want to express. However, from group 2 and group 3, the perception was different. They presented priority to the textual organisation (item 5/D) by the rank mean of (group $2 \mu=2.45$ and group 3 $\mu=2.00)$.

These findings suggested that EFL learners with little English writing experience (group 1) held the belief that poor content is not as problematic as linguistic inaccuracy because writing is a means to improve their English abilities or because the essays are read and corrected by the language teacher. Their focus was on the form of their essays rather than on the content conveyed. Next, results indicated that students of the lower group (group 1) spent most of their composing time thinking of the vocabulary and expression they wanted (items B) and the proper structure that they want to use (item C) whereas the other groups (group 2 and group 3) spent most time on generating ideas (item A) and text organization (item B). This finding suggests that students who had not received high English writing scores (group 1) were very likely due to a lack of awareness on the requirements and efforts needed in undertaking the writing task in English.

\subsection{Perceptions of Writing}

Spearman's correlation coefficients were computed to measure the level of relationship between writing performance and the importance of the items of a question. The sum of each item's rank of questions regarding perceive approaches of good writing was correlated separately with English writing scores. Results show that English writing scores were significantly correlated with item-a (reading and more writing practice) (rho $=0.318, \mathrm{p}<0.05)$, item-b (vocabulary, idioms, and phrases) (rho $=-0.425, \mathrm{p}<0.01)$, item-c (proper grammar and structure) (rho $=-0.344, \mathrm{p}<$ $0.05)$, item-d (how to organize a text) (rho $=0.416, \mathrm{p}<.01)$. 
Table 8. Relationship between metacognitive knowledge and writing performance

\begin{tabular}{|c|c|c|c|}
\hline & & reading and more writing practice & Writing score \\
\hline \multirow{3}{*}{$\begin{array}{c}\text { reading and more writing } \\
\text { practice }\end{array}$} & Correlation Coefficient & 1.000 & $.318^{*}$ \\
\hline & Sig. (2-tailed) & . & .025 \\
\hline & $\mathrm{N}$ & 50 & 50 \\
\hline \multirow[t]{4}{*}{ Writing score } & Correlation Coefficient & $.318^{*}$ & 1.000 \\
\hline & Sig. (2-tailed) & .025 & . \\
\hline & $\mathrm{N}$ & 50 & 50 \\
\hline & & vocabulary, idioms, and phrases & Writing score \\
\hline \multirow{3}{*}{$\begin{array}{c}\text { vocabulary, idioms, and } \\
\text { phrases }\end{array}$} & Correlation Coefficient & 1.000 & $-.425^{* *}$ \\
\hline & Sig. (2-tailed) & . & .002 \\
\hline & $\mathrm{N}$ & 50 & 50 \\
\hline \multirow[t]{4}{*}{ Writing score } & Correlation Coefficient & $-.425^{* *}$ & 1.000 \\
\hline & Sig. (2-tailed) & .002 & . \\
\hline & $\mathrm{N}$ & 50 & 50 \\
\hline & & proper grammar and structure & Writing score \\
\hline \multirow{3}{*}{$\begin{array}{l}\text { proper grammar and } \\
\text { structure }\end{array}$} & Correlation Coefficient & 1.000 & $-.344^{*}$ \\
\hline & Sig. (2-tailed) & . & .014 \\
\hline & $\mathrm{N}$ & 50 & 50 \\
\hline \multirow[t]{4}{*}{ Writing score } & Correlation Coefficient & $-.344^{*}$ & 1.000 \\
\hline & Sig. (2-tailed) & .014 & . \\
\hline & $\mathrm{N}$ & 50 & 50 \\
\hline & & how to organise a text & Writing score \\
\hline \multirow[t]{3}{*}{ how to organize a text } & Correlation Coefficient & 1.000 & $.416^{* *}$ \\
\hline & Sig. (2-tailed) & . & .003 \\
\hline & $\mathrm{N}$ & 50 & 50 \\
\hline \multirow[t]{3}{*}{ Writing score } & Correlation Coefficient & $.416^{* *}$ & 1.000 \\
\hline & Sig. (2-tailed) & .003 & . \\
\hline & $\mathrm{N}$ & 50 & 50 \\
\hline
\end{tabular}

**. Correlation is significant at the 0.01 level (2-tailed).

*. Correlation is significant at the 0.05 level (2-tailed).

According to Cohen's (1988) guidelines, English writing performance was positively related to an emphasis on the discourse level (item-a, item-d) and negatively related to the level of emphasis on lexical and grammatical concerns (item-b, item-c). In contrast, correlations of Persian writing scores and the sum of a perceived item's rank of questions were not significant (all the p-values > .05). There appears to be no possible link between Persian writing performance and each perceived item.

\section{Discussion}

\subsection{Perceptions Regarding Persian and English Writing}

Results show that students had different beliefs about composing in Persian and English. Students' perceptions of Persian writing were generally consistent across groups, with only small variations. Students shared a similar view as to what the nature and concerns of the Persian writing task should be. A relationship existed between the criteria they perceived as necessary for quality writing and their efforts. Hence, their knowledge of Persian writing was appropriate. 
The overall pattern of their perceptions of English writing changed across their level of writing scores. Most students, especially in the low-score group (group 1), did not have sufficient information to determine the demands and processes necessary in undertaking an English writing task. They believed that excellent writing mostly requires proper vocabulary or syntax. For these students, writing in English was a matter of working memory b controlled by language issues, instead of content and rhetoric issues. Consequently, these writers were likely to become anxious while trying to recall the correct words and grammar (Victori, 1999; Lane, Graham, Harris \& Weisenbach, 2006; de Larios, Manchón, Murphy \& Marín, 2008; Ruan, 2014). Attention to the micro-level of a text rather than the macro-level may have been due to their lack of knowledge of English writing conventions. Moreover, the students' view of English writing tasks as a means of second language learning may result from previous criticism on their Persian writing, which reflected expectations of polished language, rather than of revisions at a text level.

Most students at the mid and high level of scores (group 2 and group 3) confirmed a change in significant terms, from linguistic forms toward a more general picture of writing a text. After having been provided with a knowledge base about English writing conventions, students were more likely to move toward an emphasis on the organisational forms and rhetorical structures of writing in English.

Results of questions about perceived problems in writing in English show that most of the participants from group 1 felt overwhelmed by their lack of vocabulary proficiency. This may reflect the necessary of lexical features and structure that writers need to manage with while writing in English. The students' perceptions of their vocabulary and grammar shortage may influence their cognitive processes while writing (Flavell, 1979). Other studies (e.g. Golshan and Karbalaei, 2009; Rahimi, 2010) had also found that the Iranian students were mainly focused on and concerned about surface-level errors. One factor influencing the obtained results can be what the teachers emphasise in their classes (Mohan \& Lo, 1985; Jones, 2005; Loi, 2010; Taft, Kacanas, Huen \& Chan, 2011). This means that, while the teachers were worried about the style the students were using in their writings, they were, in fact, mainly focusing on teaching surface-level errors. The main concern here was that many English classes in Iran were restricted to the use of specific textbooks, and those textbooks were generally more focused on surface-level errors. Even Persian writing manuals generally focused on surface-level errors (Ghorbaniun, 2004; Solhjoo, 2008). This might be one reason why the students were unconsciously more drawn towards surface-level errors.

In summary, as students who obtained mid and high scores (group 2 and 3) in their English and Persian writing, their task knowledge of writing changed and moving from linguistic forms to textual structures. However, for students in the low-scores group (group 1), self-assessment of proficiency in English writing remained focused on the difficulty of vocabulary and suitable structure.

\subsection{Focuses on the Micro and Macro Structures}

An investigation of the relationship between the ranking of the two sub-items and writing scores showed that there was a link between students' metacognitive knowledge base and their English writing performance (Devine et al., 1993; Kasper, 1997; Yanyan, 2010; Ruan, 2014). For Persian writing, there was no significant relationship.

The results of questions about which features of English writing Iranian undergraduate students focused most and the relationship of these aspects to their writing performance provided an understanding of the order of importance of the difficulties of a writing task. In general, English writing performance had a positive correlation with content/idea (item A) and organisation (item D). This finding suggested that better writers might be concerned more with the macro structures of a text. These writers hold the belief that writing needs more attention at the text level. Their approach to writing is likely as a top-down process.

In contrast, the negative correlation of English writing scores with vocabulary (item B) and grammar (item C) suggested that lower achievers might focus a great deal on linguistic forms and structures. They may be too often constrained by the need for producing words and organising them into a sentence. They may have little cognitive capacity available to pay attention to the overall plan for a text. Likely, their approach to writing is more driven by bottom-up constraints.

The relationship between metacognitive knowledge and English writing performance found in this study agreed with the findings of studies such as Victori, (1999), Graham (2006), de Larios, Manchón, Murphy and Marín (2008), and Ruan (2014), which showed that the better writers focused on global text-level problems whereas the less effective writers' comments mostly centred on vocabulary and grammatical aspects. This is a finding that also supports L1 literature. Researchers on L1 writing (e.g. Perl, 1979; Shaughnessy, 1977; Braine, 2002; Jahin, 2012) have noted that native speakers might have difficulties in making a framework for their readers, because they continue to struggle with the production of words and sentences, and because their fear of error also stops their movement of any 
achievement.

\section{Implication of Study}

Implications from metacognitive knowledge provide perceptions into a way where teachers can help EFL student to write more effectively. Educators should include the instruction of metacognitive knowledge as one of the main element of teaching programs (Ma \& Wang, 2013). Specifically, teachers of English can design activities to help increase students' motivation and self-efficacy in writing, namely, to improve their knowledge. Teachers can also provide instruction in the use of cognitive and metacognitive strategies to support students' strategic knowledge and skills for independent learning (Ahmadi, Ismail \& Abdullah, 2013). Moreover, it is important to increase students' awareness of the specific strategies that can be employed in the writing process, such as to think from readers' perspectives, to reflect upon their writing, and to revise their compositions for improvement.

\section{Conclusion}

This study attempted to understand the knowledge and beliefs that EFL undergraduate students bring to writing tasks and how these beliefs influence their achievement in English writing. As can be observed from the results of the self-assessment instrument, there was a potential link between metacognitive knowledge and writing outcome. First, a positive link for awareness of attention to macro-structures of a text, and a negative link for most concerns about lexical and grammatical structures. As was the case with the good writers in Sasaki's study (2000), L2 learners need to pay more attention to the overall organisation while writing in L2. Furthermore, they need to delay consideration of lexical and grammatical problems and did not allow second language weakness to influence their writing process, as the better L2 writers did in Zamel's study (1983). It is marked that metacognitive knowledge is an essential part of developing writing skill.

\section{References}

Ahmadi, M. R., Ismail, H. N. \& Abdullah, M. K. K. (2013). The Importance of Metacognitive Reading Strategy Awareness in Reading Comprehension. English Language Teaching, 6(10), 235-244. https://doi.org/10.5539/elt.v6n10p235

Alderson, J. C. (1984). Reading in a foreign language: A reading or a language problem? In J. C. Alderson \& A. H. Urquhart (Eds.), Reading in a foreign language (pp. 1-24). London: Longman.

Bereiter, C. \& Scardamalia, M. (1987). The psychology of written composition. Hillsdale, NJ: Lawrence Erlbaum.

Biggs, J., Lai, P., Tang, C. \& Lavelle, E. (1999). Teaching writing to ESL graduate students: A model and an illustration. British Journal of Educational Psychology, 69, 293-306. https://doi.org/10.1348/000709999157725

Braine, G. (2002). Academic literacy and the nonnative speaker graduate student. Journal of English for academic purposes, 1(1), 59-68. https://doi.org/10.1016/S1475-1585(02)00006-1

Cava, M. T. (1999). Second language learner strategies and the unsuccessful second language writer. Unpublished $\mathrm{PhD}$, Columbia University, New York.

Chao, Y. C. J. (2003). Contrastive rhetoric, lexico-grammatical knowledge, writing expertise, and metacognitive knowledge: An integrated account of the development of English writing by Taiwanese students (China) (Doctoral dissertation, ResearchSpace@ Auckland).

Cohen, J. (1988). Statistical power analysis for the behavioral sciences (2nd ed.). Hillsdale, NJ: Lawrence Erlbaum.

de Larios, J. R., Manchón, R., Murphy, L. \& Marín, J. (2008). The foreign language writer's strategic behaviour in the allocation of time to writing processes. Journal of Second Language Writing, 17(1), 30-47. https://doi.org/10.1016/j.jslw.2007.08.005

Devine, J., Railey, K. \& Boshoff, P. (1993). The implications of cognitive models in L1 and L2 writing. Journal of Second Language Writing, 2(3), 203-225. https://doi.org/10.1016/1060-3743(93)90019-Y

Diab, R. L. (2005). Teachers' and students' beliefs about responding to ESL writing: A case study. TESL Canada Journal, 23(1), 28-43. https://doi.org/10.18806/tesl.v23i1.76

Diab, R. L. (2006). Error correction and feedback in the EFL writing classroom: Comapring instructor and studnet preferences. English Teaching Forum, 3, 1-14.

Flavell, J. H. (1979). Metacognition and cognitive monitoring: A new area of cognitive-developmental inquiry. American psychologist, 34(10), 906. https://doi.org/10.1037/0003-066X.34.10.906

Flavell, J. H. (1985). Cognitive development (2nd ed.). Englewood Cliffs, NJ: Prentice-Hall. 
https://doi.org/10.1037/0003-066X.34.10.906

Freedman, A., Pringle, I. \& Yalden, J. (1983). The writing process: Three orientations. In A. Freedman \& I. Pringle \& J. Yalden (Eds.), Learning to write: first language/ second language (pp. 1-15). New York: Longman.

Ghorbaniun, H. (2004). Methods of written and spoken presentation.

Golshan, M. \& Karbalaei, A. (2009). Grammatical problems in the writings of EFL undergraduate learners. South Asian Language Review, 19(1), 1-10.

Grabe, W. (2001). Notes toward a theory of second language writing. In T. Silva \& P. K. Matsuda (Eds.), On second language writing (pp. 39-57). Mahwah, NJ: Lawrence Erlbaum Associates.

Hayes, J. (1996). A new framework for understanding cognition and affect in writing. In C. M. Levy \& S. Ransdell (Eds.), the science of writing (pp. 1-27). Mahwah, NJ: Lawrence Erlbaum Associates.

Hayes, J. R. \& Flower, L. S. (1980). Identifying the organization of writing processes. In L. W. Gregg \& E. R. Steinberg (Eds.), Cognitive processes in writing (pp. 3-30). Hillsdale, NJ: Lawrence Erlbraum.

Horwitz, E. K. (1987). Surveying student beliefs about language learning. In A. L. Wenden \& J. Rubin (Eds.), Learner strategies in language learning (pp. 119-129). Eaglewood Cliffs, NJ: Prentice-Hall.https://doi.org/10.18806/tesl.v23i1.76

Jahin, J. H. (2012). The Effect of Peer Reviewing on Writing Apprehension and Essay Writing Ability of Prospective EFL Teachers. Australian Journal of Teacher Education, 37(11), n11. https://doi.org/10.14221/ajte.2012v37n11.3

Kasper, L. F. (1997). Assessing the metacognitive growth of ESL student writers. TESL-EJ, 3(1), 1-20 (available online at www-writing.berkeley.edu/TESL-EJ/ej09/al.html).

Lane, K. L., Graham, S., Harris, K. R. \& Weisenbach, J. L. (2006). Teaching writing strategies to young students struggling with writing and at risk for behavioral disorders: Self-regulated strategy development. Teaching Exceptional Children, 39(1), 60-64. https://doi.org/10.1177/004005990603900109

Loi, C. K. (2010). Research article introductions in Chinese and English: A comparative genre-based study. Journal of English for Academic Purposes, 9(4), 267-279. https://doi.org/10.1016/j.jeap.2010.09.004

McCutchen, D., Francis, M. \& Kerr, S. (1997). Revising for meaning: Effects of knowledge and strategy. Journal of Educational Psychology, 89, 667-676. https://doi.org/10.1037/0022-0663.89.4.667

Mohan, B. A. \& Lo, W. A. Y. (1985). Academic writing and Chinese students: Transfer and developmental factors. Tesol Quarterly, 19(3), 515-534. https://doi.org/10.2307/3586276

Mu, C. \& Carrington, S. B. (2007). An investigation of three Chinese students' English writing strategies. Teaching English as a Second or Foreign Language-EJ, 11(1), 1-23.

Nation, I. S. P. \& Hwang, K. (1995). Where would general service vocabulary stop and special purposes vocabulary begin? System, 23(1), 35-41. https://doi.org/10.1016/0346-251X(94)00050-G

Perl, S. (1979). The composing processes of unskilled college writers. Research in the Teaching of English, 13, 317-336.

Rahimi, M. (2010). Iranian EFL students' perceptions and preferences for teachers' written feedback: Do studnets' ideas reflect teachers' preactice? The Journal of Teaching Language Skills, 2(2), 75-98.

Raimes, A. (1987). Language proficiency, writing ability, and composing strategies. Language Learning, 37, $439-468$. https://doi.org/10.1111/j.1467-1770.1987.tb00579.x

Raimes, A. (1991). Out of the woods: Emerging traditions in the teaching of writing. TESOL Quarterly, 25, $407-430$. https://doi.org/10.2307/3586978

Ruan, Z. (2014). Metacognitive awareness of EFL student writers in a Chinese ELT context. Language Awareness, 23(1-2), 76-91. https://doi.org/10.1080/09658416.2013.863901

Saneh, N. A. (2009). Intercultural rhetoric in higher education: The case of Iranian students' textual practices in North American graduate schools. University of Ottawa.

Sasaki, M. (2000). Toward an empirical model of EFL writing processes: An exploratory study. Journal of second language writing, 9(3), 259-291. https://doi.org/10.1016/S1060-3743(00)00028-X 
Schulz, R. A. (2001). Cultural differences in student and teacher perceptions concerning the role of grammar instruction and corrective feedback: USA-Columbia. The Modern Language Journal, 85, 244-258. https://doi.org/10.1111/0026-7902.00107

Shaughnessy, M. (1977). Errors and expectations: A guide for the teacher of basic writing. New York: Oxford University Press.

Solhjoo, A. (2008). Remarks on editing. Tehran: Nashr-e-markaz Publications.

Taft, M., Kacanas, D., Huen, W. \& Chan, R. (2011). An empirical demonstration of contrastive rhetoric: Preference for rhetorical structure depends on one's first language. Intercultural Pragmatics, 8(4), 503-516. https://doi.org/10.1515/iprg.2011.023

Victori, M. (1999). An analysis of writing knowledge in EFL composing: A case study of two effective and two less effective writers. System, 27, 537-555. https://doi.org/10.1016/S0346-251X(99)00049-4

Wenden, A. L. (1999). An introduction to metacognitive knowledge and beliefs in language learning: beyond the basics. System, 27, 435-441. https://doi.org/10.1016/S0346-251X(99)00043-3

Wolfe, C. R., Britt, M. A. \& Butler, J. A. (2009). Argumentation schema and the myside bias in written argumentation. Written Communication, 26(2), 183-209. https://doi.org/10.1177/0741088309333019

Yanyan, Z. (2010). Investigating the role of metacognitive knowledge in English writing. HKBU Papers in Applied Language Studies, 14, 25-46.

Zamel, V. (1983). The composing processes of advanced ESL students: Six case studies. TESOL Quarterly, 17, 165-187. https://doi.org/10.2307/3586647

ZIA, H. S. \& Derakhshan, K. (2006). Transfer of first language of foreign language writing: A contrastive rhetoric study of English \& Farsi. 